\title{
Opciones visuales en torno a la protesta obrera. De La hora de los hornos (1968) a Los traidores (1973) ${ }^{1}$
}

\author{
Mariano Mestman \\ UBA-CONICET
}

A Humberto Barroso y Octavio Getino

In memoriam

Obreros detrás del enrejado perimetral de las fábricas, subidos a los techos, con carteles y banderas, ocupando las instalaciones; trabajadores movilizados, en manifestaciones masivas, organizando barricadas en las calles, enfrentándose con la policía. Se trata, lo sabemos, de imágenes típicas del conflicto gremial durante el siglo XX que encontramos en casi todas las películas sobre el tema, sea como registro directo, incorporado como archivo o reconstruido, escenificado ad hoc en un film documental o de ficción. Si pensamos en el cine argentino de intervención política de fines de la década de 1960 e inicios de la siguiente, las imágenes del Cordobazo se imponen como principal referencia visual de las luchas obreras. Presentes en casi todos los films, emblematizando un punto de inflexión en la historia política nacional, de algún modo desplazaron de nuestra memoria otras secuencias del accionar sindical. Sin embargo, hubo otras imágenes que en muchos casos compartieron con las del estallido cordobés -y otras veces le disputaron- la simbolización de las luchas del período. Entre ellas, las de ocupaciones fabriles.

\section{Un archivo recurrente}

No nos detendremos aquí en los sucesos del 29 y 30 de mayo de 1969 en Córdoba, durante el gobierno militar del general Juan Carlos Ongania, respecto del cual existe una importante bibliografia. Como se sabe, hay coincidencia en que este episodio alteró por su envergadura

1. Agradezco los comentarios de Pablo Ghigliani para el presente artículo. 
el clima político nacional (junto a las revueltas previas y posteriores de ese mismo año, como los Rosariazos). En lo inmediato, los estallidos precipitaron la caída de Onganía al año siguiente; y en adelante el Cordobazo, "nuestra Comuna" (Ghigliani, 2009), configuró un símbolo de la insurrección popular al abrir un período de "lucha de calles" y, en especial en Córdoba, apuntalar el desarrollo de tendencias clasistas en importantes sindicatos.

Las imágenes del hecho captadas por las cámaras de la televisión llevaron a los hogares la irrupción violenta de la protesta, dando cuenta del desorden y la confusión reinante en un primer momento mientras los enfrentamientos tenían lugar en el casco céntrico de la ciudad. Los movimientos rápidos de cámara a altura humana, en medio de las corridas, los gases y los disparos, transmitian lo vertiginoso de los hechos. Los titubeos de la cámara al hombro reponían la sensación de sorpresa e imprevisibilidad; de lo incontrolado de los acontecimientos captados (Varela, 2005: 236).

Pero desde el momento mismo de su registro, esas imágenes televisivas estuvieron en disputa. No sólo porque fueron acompañadas por las palabras de los corresponsales que las enviaban, y en su transmisión (que no fue directa, en vivo, sino al día siguiente y en los sucesivos) se presentaron editadas y "comentadas" de diverso modo. También porque fueron apropiadas y resignificadas por el cine político. En un trabajo anterior (Mestman y Peña, 2002), estudiamos cómo casi todas las películas militantes de la década que siguió al hecho (1969-1979), se refirieron al Cordobazo utilizando un mismo fragmento televisivo para representarlo como inflexión histórica y proclamar que a partir de alli se generalizaba la protesta antidictatorial, las clases populares retomaban la iniciativa o se producía un salto cualitativo. Ese fragmento de archivo recurrente muestra a la policía montada avanzando por una calle a todo galope hacia un grupo de manifestantes mientras éstos comienzan a arrojarle piedras y cascotes hasta que los jinetes de modo desordenado y precipitado dan media vuelta en súbita retirada.

El uso de estas imágenes da cuenta del funcionamiento del cine militante frente a los posibles "límites" del registro televisivo de este tipo de hechos. Interesado en el "efecto directo" de las imágenes por la autenticidad y potencial identificación que aportan las tomas desde el interior mismo de las movilizaciones, el cine político se preocupa al mismo tiempo por achicar lo más posible los márgenes de ambigüedad. La selección de ese fragmento y su significación (también) desde las voces de autoridad de los films resultan imprescindibles cuando se trata de expresar las tesis militantes que interpretan el acontecimiento: desde la referencia, apenas producidos los hechos, en Ya es tiempo de violencia (Enrique Juárez, 1969) al momento en que "comenzamos 
a ser nosotros los dominadores de la situación" o, en el fragmento de Pablo Szir del film colectivo Los caminos de la liberación (Realizadores de Mayo, 1969), donde se afirma "a cascotazos limpios los hicimos retroceder", pasando por la consideración de que "la marea empezaba a darse vuelta" (Operación Masacre, de Jorge Cedrón, 1972-1973), hasta las reconstrucciones posteriores al golpe militar de 1976 que ubican en el Cordobazo el origen de "un nuevo entusiasmo y confianza (de) las masas", en Las vacas sagradas (Jorge Giannoni-Alvaro Melián, 1977), "una victoria obrera entre las llamas", en Montoneros. Crónica de una guerra de liberación (Ana Amado-Nicolás Casullo, 1976), o el "retroceso de los verdugos", en Resistir (Julián Calinki/Jorge Cedrón, 1978). En otros casos, esas imágenes emblemáticas se (re)significaron al compaginarse con canciones de protesta como la Marcha de la bronca en Los traidores (Raymundo Gleyzer, 1973) o con el propio Himno Nacional en La tortura politica en Argentina, 1966-1972 (Carlos Vallina y otros, 1972). Y aún en casos en que esa secuencia no se incorpora a los films, es "sustituida" por otros registros o reconstrucciones ad hoc con un significado similar de avance del pueblo y retroceso de las fuerzas represivas, como ocurre en Los hijos de Fierro (Fernando Solanas, 1975).

De este modo, en estas (y otras) películas el Cordobazo se lee como punto de inflexión en la serie histórica, y sus imágenes simbolizan una épica de insurrección obrera y popular. Pero hay diferencias en la significación histórica atribuida al hecho entre los realizadores vinculados al peronismo y aquellos vinculados a la izquierda marxista. Mientras en los primeros se observa una tendencia a ubicar el acontecimiento como un momento más (aún cuando destacado) de las luchas de la Resistencia desde 1955 -e incluso en algún caso como el punto de llegada más alto y que abriria una nueva etapa en la que Perón o el peronismo ocuparian un lugar protagónico-, en los segundos se focaliza en cómo el Cordobazo expresaría la aparición de una alternativa revolucionaria clasista, independiente de viejos liderazgos políticos o sindicales.

\section{La palabra obrera}

La "toma de la palabra", tal como fue pensada en relación con los sucesos del 68 en el plano mundial, se produce en primera instancia en "acto", es decir, durante el hecho mismo: las masas / los sujetos en las calles de Córdoba, ocupando la ciudad, construyendo barricadas, se expresan con su cuerpo y su voz. Al quemar ciertos locales del poder económico, y no otros; al destrozar las vidrieras, sin robar; al colgar ciertos carteles, pronunciarse en asambleas, etc., irrumpen en la escena política, y significan su protesta. Pero al momento de ser mediatizada por el cine político, su palabra propiamente dicha sigue diversos caminos. 
Uno de ellos es el recorrido en dos películas realizadas apenas ocurridos los hechos: un corto de Pablo Szir incorporado en El camino de la liberación, film colectivo del grupo Realizadores de Mayo compuesto por diez cortometrajes; ${ }^{2}$ y el largometraje documental Ya es tiempo de violencia, de Enrique Juárez. Ambos materiales documentales se singularizan por el modo en que introducen testimonios de obreros participantes de la revuelta, ya que los sintetizan y recrean en una voz protagónica.

Ya es tiempo de violencia comienza con una voz over dominante que luego de unos minutos cede la autoridad textual al testimonio (también en off) de un obrero que reconstruye su vivencia personal de los hechos. De este modo, el registro de la voz se modifica: ya no se trata de la retórica (neutra o solemne) del narrador, sino de la palabra de un "compañero", desplegada en un lenguaje más coloquial y que pasa por las tres secuencias temporales "clásicas" del Cordobazo: 1) la salida de las columnas masivas desde los lugares de trabajo en la mañana del 29 de mayo; 2) el asesinato al mediodía del obrero Máximo Mena, la escalada en el enfrentamiento, la ocupación de zonas de la ciudad y la superación de la policía por los manifestantes; 3) la irrupción del ejército desde esa tarde/noche y la recuperación de la ciudad al día siguiente. Esta voz obrera participa de modo notable de la interpretación de los hechos y es incluso la que "ancla" el sentido de las citadas secuencias de los manifestantes haciendo retroceder a la policía montada.

Según sabemos, este relato fue reconstruido por Enrique Juárez en base a entrevistas a partícipes del Cordobazo, y fue puesto en la voz de un actor. Aunque, entonces, tendria su origen en testimonios "verdaderos" (en esas entrevistas a protagonistas reales), en su configuración final para el film esa palabra obrera asume una identidad singular, selectiva respecto del universo de ideologías e identidades gremiales y políticas presentes en las calles de Córdoba y que sin duda resulta afin a la posición del cineasta en esa coyuntura. Como si fuera "al pasar" nos enteramos que quien habla es un obrero mecánico afiliado al sindicato SMATA (uno de los más movilizados durante las jornadas de mayo), que durante los años previos, viviendo en Buenos Aires o en Córdoba, adhirió al peronismo y sus conquistas, y que al mismo tiempo reivindica la democracia sindical antiburocrática que conoció al llegar a Córdoba. ${ }^{3}$

2. Realizados por: Mauricio Berú, Nemesio Juárez, Rodolfo Kuhn, Octavio Getino, Jorge Martín (Catú), Humberto Ríos, Rubén Salguero, Eliseo Subiela, Pablo Szir.

3. La revista Cine Cubano ( ${ }^{\circ}$ 63-65, 1970: 37-40) reprodujo el testimonio obrero del film, con variaciones mínimas y con la aclaración de que se trataba de una "recopilación, de tres que se hicieron", reelaborada por los autores, sacándole las preguntas, y "dicha por un actor". Por su parte, Pablo Pozzi y Alejandro Schneider reprodujeron un testimonio atribuido a un obrero mecánico, que es probable que se trate de una de las tres entrevistas compiladas. Lo citan como perteneciente a "Martín" y "regis- 
Por su parte, el corto de Pablo Szir es el único de los que integra $\mathrm{El}$ camino de la liberación que trabaja sobre las imágenes del Cordobazo siguiendo un testimonio obrero. También aquí es una sintesis de testimonios reales, emitida en off por la voz de un actor. En este caso las imágenes de los hechos se intercalan con otras de los días posteriores que muestran sus consecuencias. De este modo, el corto se inicia con el regreso de un trabajador a su fábrica, la IKA Renault, pocos días después del estallido. El viaje en autobús le permite reflexionar con un monólogo interior mientras observa los vestigios, las huellas de la revuelta: pintadas en las paredes, destrozo de locales o autos quemados. Desde allí, estas imágenes de días posteriores se intercalan con las del Cordobazo. La primera persona (también aquí un obrero peronista) refiere con frecuencia, como en el otro caso, a un nosotros inclusivo que relata los sucesos siguiendo la cronología clásica referida, construye una épica del más débil que va perdiendo el miedo al sentirse entre sus compañeros y formula la justicia del accionar colectivo ("la violencia justa, limpia, indispensable") como respuesta a la violencia oficial.

En ambos films, al caer la noche, el trabajador busca un revólver en su casa, regresa al centro de la ciudad, se esconde entre los techos y dispara contra las fuerzas represivas. En ambos casos también, el final de la palabra obrera presenta proclamas insurreccionales que expresan el significado "revelador" de la experiencia vivida, la toma de conciencia por parte del sujeto protagonista en cada caso (a lo cual la violencia contribuye de modo decisivo) y sintetizan aquello que el Cordobazo representó para gran parte de una nueva izquierda (peronista o marxista) ascendente en la Argentina: un camino que vincula la movilización gremial, la lucha de calles y la lucha armada; y que aquí es narrado por esos relatos obreros bien articulados (y a cargo de un actor, recordémoslo) pero con inflexiones retóricas que facilitan su expresión como "naturales", "cotidianos", en parte "intimos", "espontáneos". Relatos de trabajadores mecánicos, en ambos casos, que salen junto a sus compañeros en manifestación desde la fábrica, son reprimidos y en consecuencia se enfrentan con la policía, para finalmente -aún cuando de modo espontáneo, defensivo o resistente- tomar un arma y proclamar la "guerra" (revolucionaria).

Los dos films comentados culminan con un acercamiento (por zoom in o montaje) a una foto difuminada de un joven arrojando una piedra con violencia. Esta imagen fija, así como las recurrentes ya citadas $\mathrm{u}$ otras de barricadas, autos y locales incendiados, enfrentamientos

trado" por Cecilia Castelar (Nueva York, 27 de mayo de 1979, mimeo). Y afirman que "Martín" habría contado lo mismo para el documental. Agradezco a Pozzi la precisión sobre esta fuente (Pozzi y Schneider, 2000). 
callejeros, se configuran a partir del Cordobazo en símbolos visuales destacados de la insurrección en la Argentina. Pero si bien podian ser las más representativas de la coyuntura, no eran las únicas disponibles, ni fueron las únicas utilizadas.

\section{Las ocupaciones fabriles}

Junto a las huelgas y movilizaciones, las ocupaciones de establecimientos laborales cobraron relevancia como medio de acción directa de la clase obrera argentina desde la caída del peronismo en 1955. En especial, como se sabe, hacia mayo-junio de 1964 se verifica un proceso de ocupación singular, un hecho "cualitativamente distinto" respecto de acciones previas por su carácter masivo, a nivel nacional, con dirección centralizada, alta planificación, con un programa común (y que incluyó acciones clandestinas o momentos de radicalización y violencia). Se trató de la segunda fase de un Plan de Lucha de la CGT programado en cinco etapas que se extendió entre mayo de 1963 y octubre de 1965 (véase Cotarelo y Fernández, 1995; Bisio y Cordone, 1989; Bourdé, 1978; Schneider, 2005 y 2009).

La experiencia en torno a tomas de fábricas fue recuperada por el principal grupo del cine político argentino, Cine Liberación, un año antes del Cordobazo, en La hora de los hornos (Solanas y Getino, 1966-1968), así como en films posteriores como El camino hacia la muerte del viejo Reales de Gerardo Vallejo (1968-1971) o Los hijos de Fierro de Solanas (1972-1975), otorgándole siempre un lugar privilegiado.

En La hora de los hornos, en su segunda parte, se le dedicó un famoso capitulo titulado "Las ocupaciones fabriles", donde se las consideraba "el punto más alto alcanzado por la Resistencia". Al igual que en otros capítulos, la voz over dominante introduce y cierra el de las ocupaciones expresando el punto de vista del film a partir de recuperar y generalizar testimonios de dirigentes de base (delegados de comisión interna) de dos establecimientos fabriles, ambos en el Gran Buenos Aires, y en dos de los sectores con más peso en el movimiento obrero sesentista, el metalúrgico y el textil. Por un lado, se exhibe la ocupación de Siam Monte Chingolo. La puesta en escena documental de este episodio participa de la épica de la Resistencia que permea todo el film. A través del testimonio a cámara, un ex delegado de comisión interna rememora los aspectos organizativos de la toma, la preparación de la autodefensa y la solidaridad barrial. Y en particular se reconstruye el intento de desalojo con un ingenioso montaje alternado del testimonio del dirigente gremial (dentro de un taller) en supuesto diálogo con el funcionario judicial llegado hasta allí, custodiado por personal civil y policial (representados por actores). Mientras el delegado metalúrgico 
relata con detalle la discusión (las palabras de cada uno), los inserts del rostro del funcionario van variando entre el enojo, la prepotencia o acaso el asombro ante la amenaza de hacer volar el establecimiento. Por su parte, en el otro conflicto reconstruido, dos jóvenes trabajadoras de la textil La Bernalesa, en Quilmes, relatan una ocupación -ilustrada con imágenes de obreras detrás de las rejas y con otras de la fábrica en pleno funcionamiento-, y en particular valoran un hecho que singularizó el caso: la solidaridad entre trabajadores y la continuación de la producción con la fábrica bajo control obrero.

Es dificil establecer una correspondencia directa entre la composición de estos episodios en el film (reconstruidos) y eventos históricos precisos; pero es interesante destacar que el capitulo en que se incluyen se refiere (por su ubicación en el film) al periodo 1962-1966, y que por otra parte se trata de establecimientos laborales donde las medidas del Plan de Lucha de la CGT de 1963-1965 habian alcanzado una cierta repercusión mediática o se habían caracterizado por aspectos particulares, recuperados en ambos casos en el film. Respectivamente: una ocupación de la planta SIAM Monte Chingolo de mediados de 1964 que -en contraste con situaciones previas- vivió una mayor presencia policial (y judicial) de corte represivo, con objetivos de desalojo (Schneider, 2005: 222-223); ${ }^{4}$ y, en segundo lugar, una ocupación de La Bernalesa en 1965 que también se había singularizado respecto del conjunto, aunque por otras razones (Schneider, 2005: 243). ${ }^{5}$

Es decir, por su cercanía temporal (respecto del inicio de las filmaciones para La hora de los hornos a fines de 1965, en particular en el segundo caso) y por su repercusión mediática (y político-gremial) se trata de hechos que pueden contarse entre las condiciones discursivas productivas del tipo de configuración que asumieron en el film. Pero, al mismo tiempo, también otros hechos o discursos influyen en la configuración final de esos episodios, incluso la experiencia política (también sindical) de algunos de los cineastas. En el grupo Cine Liberación, por ejemplo, es

4. Ésta había sido una característica de las últimas jornadas del Plan de Lucha de mayo-junio de 1964. Por ejemplo, la del 24 de junio de 1964, en la que participaron cerca de 1.150 .000 trabajadores que ocuparon alrededor de 4 mil establecimientos, o la del día 18 que habrian tenido características especiales, similares a las relatadas en el film. Schneider remite, entre otros, al caso de Siam de Monte Chingolo.

5. Schneider (2005: 243) observa la repercusión pública del hecho. Originado en el reclamo del cobro de quincenas adeudadas, la toma de La Bernalesa se desencadenó por el anuncio de su cierre temporal. "Lo notable de esta ocupación fue que se mantuvo pese a que la Subsecretaría de Trabajo de la Provincia de Buenos Aires había fallado a favor de los operarios (... es decir, se mantuvo por desconfianza a que se cumpliese el fallo). Los obreros pusieron la planta en funcionamiento, desoyendo los consejos de la dirección del gremio que sugirió abandonar las instalaciones." 
el caso de Octavio Getino, quien desde la caída misma del peronismo en 1955 participa de una agrupación trotskista pro-peronista y se inserta en el ámbito gremial: viviendo en Temperley, Getino tenía cierta vecindad con la familia Taborda, varios de cuyos miembros participan del film (como Rudi, la delegada que relata la toma de La Bernalesa); y en esos años comenzó él mismo a trabajar en Carma-Siam Monte Chingolo, una fábrica de electrodomésticos que al poco tiempo incorporó armado de autopartes, según recuerda. Allí, siendo delegado de los empleados, tenía una fluida relación con los delegados obreros, entre ellos, Cirilo Ramallo, justamente quien es entrevistado por Getino en el film para que reconstruya la toma en el primer episodio que comentamos. ${ }^{6}$

Pero el capítulo "Las ocupaciones fabriles" no es el único que aborda esa experiencia obrera. Por el contrario, en muchos de los episodios previos de la segunda mitad de la segunda parte de La hora de los hornos (titulada "La Resistencia"), la misma también asume un lugar relevante. De hecho, las imágenes de ocupaciones (sea por su referente histórico o por los relatos, las narrativas en que se incluyen) están presentes en todos los capítulos referidos a la acción obrera desde la caída del peronismo. Junto a las imágenes de archivo "genéricas", que aluden a significantes visuales y sonoros típicos (puertas y portones cerrados, móviles policiales en el exterior, masas obreras agrupadas tras las rejas o alambrado, carteles con reclamos o con la consigna "fábrica ocupada", bullicio de multitudes, sonido de sirenas, etc.), las imágenes "específicas" reenvian a hechos históricos puntuales. En particular a acontecimientos de la coyuntura de mediados de la década de 1960 que, como ya mencionamos, es la inmediatamente anterior al inicio de la filmación.

Por ejemplo, el famoso afiche de Ricardo Carpani titulado "Basta" abre el capítulo dedicado a la crónica del período 1955-1958. Aún cuando en esos años la primer Resistencia es asociada a acciones más dispersas y espontáneas, se elige este afiche que había sido elaborado para la Semana Nacional de Protesta (27 al 31 de mayo de 1963) convocada por la CGT reunificada bajo la dirección de José Alonso en los inicios de ese Plan de Lucha Nacional, caracterizado en cambio

6. Testimonio de Getino al autor. Getino mantuvo una actividad gremial trabajando como peón o empleado en distintos establecimientos (además de SIAM, una fábrica de relojes, la textil Alpargatas en Barracas, Otis Ascensores), a veces por períodos cortos, entre 1956 y 1962 o 1963 cuando comienza a vincularse a la actividad cinematográfica. En ese proceso, a fines de la década de 1950, se alejó del trotskismo para insertarse en el peronismo "antiburocrático", como lo llama el propio cineasta. Cuando le consultamos sobre este episodio del film, se refirió a una gran huelga y ocupación que ubicó entre 1956 y 1957. También Ramallo en el film refiere a que se trató de la "segunda fábrica tomada en el país" (se entiende desde el inicio de la Resistencia) a raíz del despido de 300 trabajadores. 
por la señalada alta organización y planificación. Es decir, una opción visual -seleccionada entre el conjunto de la extensa gráfica política de Carpani- distante del período histórico abordado; pero que aún así tal vez resultaba pertinente para apelar a la memoria reciente del tipo de espectador al que buscaba dirigirse esta segunda parte del film cuando comenzó a exhibirse en un circuito paralelo en la Argentina desde fines de 1968. Porque este afiche de la CGT (publicado también en su boletín) había alcanzado una amplia difusión al cubrir las paredes de las principales ciudades del país y en tanto objeto de polémicas en la prensa politica alternativa, ${ }^{7}$ y porque Ricardo Carpani recorrería desde aquel momento un camino de definiciones que lo alejaria de la CGT oficial poco después, cuando la hegemonía vandorista, y lo acercaria al peronismo revolucionario, para vincularse hacia 1968 a la CGT de los Argentinos, esto es, el mismo ámbito donde confluiría en esa coyuntura el grupo Cine Liberación. ${ }^{8}$

Si bien a lo largo del documental se incorporan otras gráficas de Carpani, este afiche "Basta" tiene un lugar destacado, ya que se ubica en la apertura misma de la crónica de la Resistencia. La cámara focaliza en una zona del mismo donde se destaca la sigla CGT (a lo cual sigue un montaje de otros fragmentos: focalización en rostros, puño de la mano, la palabra "Basta"). Un tipo de composición visual que destaca la sigla cegetista y se acompaña en off por la consigna "el peronismo es el hecho maldito del sistema" (que remite a la frase de John William Cooke), fundamentada en el rol clave que habrian tenido las organizaciones sindicales en provocar la "crisis de las instituciones demoliberales". A partir de allí, mientras la voz over recorre los hitos del proceso político y la acción obrera en esos años -pese a los despidos ${ }^{9}$ y persecuciones-, la banda de imagen incorpora títulos e ilustraciones de la prensa obrera clandestina así como imágenes de hechos y personajes propios de

7. En 1963, en polémica con las críticas recibidas que cuestionaban el afiche en tanto "autorretrato totalitario" de los "autócratas de la CGT", el periódico del peronismo revolucionario Compañero (16/06/1963) lo consideraba en cambio expresión de las bases trabajadoras, rescatando su contenido "emotivo e ideológico", su mensaje "insurreccional y revolucionario", que "excedia en mucho las intenciones de la dirección cegetista”.

8. En entrevistas que realicé a militantes y dirigentes de la CGTA entre 1992 y 1995, varios se refirieron a su colaboración con la difusión clandestina de La hora de los hornos. Entre otros: Enrique Coronel (ferroviarios), Ricardo de Luca (navales), Alfredo Ferraresi (farmacia), el "Gato" Goldar (gráficos) o Héctor Quagliaro (ATE-CGTA, Rosario).

9. El capítulo se cierra con otro afiche de Carpani que expone obreros desocupados en las afueras de una fábrica, que parecen vencidos o a la espera, bajo el título "A esto nos llevaron los que nos gobiernan" y firmado por la CGT. 
esos primeros años pero también de los posteriores: la citada gráfica de Carpani, secuencias filmicas de archivo de dirigentes (como José Alonso y Augusto Vandor $)^{10}$ así como de asambleas y actos montados de modo entrecortado mientras la voz over refiere al Programa Obrero de La Falda (Córdoba) de 1957.

Luego del capítulo "Los sindicatos" -que incluye la reflexión de militantes y dirigentes obreros peronistas, donde se destaca el gráfico Raimundo Ongaro-, la crónica de los hechos se retoma en el capítulo "El desarrollismo (1958-1962)", que desde el comienzo presenta secuencias de archivo del interior de establecimientos fabriles con sus trabajadores deambulando o en asamblea, de movilizaciones masivas, y del gran conflicto que inició ese año tan especial que fue 1959: en enero, la huelga y ocupación del frigorífico Lisandro de La Torre contra su privatización. Si ocupaciones previas constituían antecedentes de interés, la toma del frigorífico (el apoyo barrial/popular, los enfrentamientos y su posterior violento desalojo), sin duda configuraba una década más tarde (cuando se hace el film) un punto de referencia ineludible en la memoria de los potenciales espectadores, ya sea por su visibilidad en la agenda politica o por su recuperación como suceso legendario. ${ }^{11}$

Por su parte, es en el último capítulo de La hora de los hornos dedicado a la crónica de los hechos ("El ejército. 1962-1966") en el que se desarrolla el Plan de Lucha de la CGT, profundizado en 1964, según se afirma. Aquí, el abanico de referencias visuales a ese proceso es de lo más variado: desde un cartel a mano que indica "fábrica tomada", portado por un trabajador, u otros también de factura manual colocados en diversas instalaciones, hasta el afiche oficial de la CGT con la Quinta Etapa del Plan de Lucha (1965) desplegado sobre una mesa de oficina de alguna sede sindical; desde trabajadores reunidos en las calles, en la entrada de los establecimientos, hasta otros ocupando instalaciones (como una breve secuencia de donde se extrajo la famosa foto de la obra

10. Aún incorporados al pasar ilustran la afirmación en over de que los "sindicatos son el principal baluarte politico del movimiento en cada comicio". En capitulos posteriores otras imágenes de archivo de Vandor se editan con la referencia de cómo en 1959 ante la masividad de las luchas "se hacen tan evidentes las limitaciones de muchas direcciones político sindicales”, y más adelante se lo verá en la asunción del general Onganía, cuando el golpe de 1966.

11. A pesar de que se trata de un tipo de conflicto que según la especialista Irene Marrone aparece sólo de modo excepcional en el noticiario cinematográfico, por lo menos hasta ese momento. En este caso, no son las imágenes de la nota número 132 del noticiaro Argentina al día, incluida en el DVD que acompaña el volumen de Marrone y Moyano Walker (2006). Se trata en cambio de otras imágenes, en las que se destacan algunas breves (sin audio) del dirigente combativo peronista Sebastián Borro hablando a sus compañeros del frigorífico. Sobre esa experiencia histórica, véanse los estudios de Ernesto Salas. 
en construcción con los obreros subidos a los andamios y el cartel Plan de Lucha CGT / Obra ocupada UOC / Basta de hambre, reproducida en tantas revistas de la época a propósito del film); desde obreros que miran a las cámaras con orgullo de su compromiso por el cumplimiento del Plan de Lucha (según indican también carteles colocados), hasta dirigentes hablando por teléfono como organizando la acción desde los sindicatos (incluso también alguna referencia visual a toma de facultades en adhesión). De este modo, las imágenes intentan dar cuenta de la dimensión cuantitativa y cualitativa de las ocupaciones fabriles, que la voz over explicita con datos estadísticos: 11.000 establecimientos ocupados; 3.000.000 de trabajadores involucrados, etc..

Ahora bien, a pesar de esta importancia atribuida entonces a esa experiencia (en lo visual y lo discursivo, en lo colectivo y lo personal: un proceso de "desalienación para el trabajador") y a pesar de la fuerza que se le reconocía ("el punto más alto alcanzado por la Resistencia", como ya dijimos), el capitulo posterior al de las ocupaciones advierte sobre el momento "crítico" al que habria arribado la "resistencia espontánea" y sobre la pérdida de "efectividad política" de los sindicatos. Todo el final de la segunda parte del film trabaja en torno a esta idea. Y en el último episodio se introducen dos testimonios de dirigentes tucumanos del ala combativa, como Leandro Fote (Secretario General del Sindicato San José) -que habla del pasaje de la lucha gremial a la política- y Andina Lizarraga (dirigente de la Juventud Peronista), quien si bien recupera las luchas previas -entre ellas las ocupaciones- postula la necesidad de la lucha armada. Sobre esto volveremos más adelante.

En sintonía con el lugar destacado que la crisis tucumana tenía en ese momento en la prensa política, sindical y nacional, todo ese final de la segunda parte del film está ocupado por imágenes del conflicto azucarero. Se trata de materiales filmicos o de entrevistas con dirigentes aportados por el cineasta tucumano Gerardo Vallejo en su colaboración para este film en el mismo proceso de su inclusión en el grupo Cine Liberación.

En este sentido, también una zona importante de El camino hacia la muerte del viejo Reales de Vallejo (realizado entre 1968 y 1971), focalizó en el conflicto en los ingenios azucareros tucumanos afectados por la política de cierre y reconversión del onganiato. A pesar de que aquí la puesta en escena de la confrontación laboral en Tucumán requirió de un tratamiento diferente -en la medida en que se trataba de retratar la vida de una familia rural, su cultura e idiosincrasia-, una zona importante del film estuvo dedicado al conflicto obrero. De hecho, Vallejo se refirió en ese momento a su intención de dar testimonio del "motor" del movimiento popular tucumano, esto es, la clase obrera rural (en particular el trabajador de la zafra azucarera, tanto el obrero de fábrica como el del 
surco), diferenciándolo de la situación en otras regiones urbanas con mayor desarrollo de clase obrera industrial. De este modo, el film recorre movilizaciones, ollas populares, represión y ocupaciones, reenviando también a momentos previos como 1965, cuando los obreros azucareros tucumanos protagonizaron el proceso "más relevante" de ocupaciones de fábrica registrados en todo el país, según se dice. ${ }^{12}$

En una suerte de anexo, la película de Vallejo presenta la historia de la lucha de la Fotia, con testimonios de obreros de base y dirigentes como Benito Romano y Raúl Zelarrayán. ${ }^{13}$ Este último narra su experiencia en la primera ocupación de un ingenio, el Santa Lucía en 1958, ${ }^{14}$ y se refiere a las dificultades que como trabajador de fábrica tenía para convencer a la gente del campo (el zafrero) de los objetivos de las medidas de fuerza. Pero afirma que luego de persuadirlos, consiguió que llevaran la caña cortada ese día a la fábrica para de ese modo batir un récord de producción con la instalación tomada por los trabajadores. Aquí se retoma desde la voz over la referencia al tema en la opera prima del grupo Cine Liberación:

Como deciamos en La hora de los hornos, las ocupaciones son hechos violentos, desalienantes; borran de la conciencia de los trabajadores una historia de mitos, saqueos y engaños. En la disputa de los medios de producción los trabajadores profundizan su descolonización. Al tomar posesión de su trabajo están tomando posesión de su humanidad.

Las imágenes en movimiento (o fijas, fotográficas) que acompañan estos testimonios son de reuniones, actos y asambleas de la Fotia, los reportajes de Vallejo a sus dirigentes, las concentraciones y movilizacio-

12. A la radicalidad y violencia social implicada en este proceso (y la toma de rehenes), se refiere Roberto Pucci (2007: 61). Por su parte, Daniel Campi y Maria Celia Bravo (2010: 30) dan cuenta del clima de radicalización que se vivía en Tucumán en 1965 al rememorar el "pacto obrero-campesino" que logró un holgado triunfo en las elecciones de ese año, permitiendo el ingreso de Fernando Riera y Benito Romano como diputados nacionales.

13. Ambos integrarian el Secretariado de FOTIA hacia 1968. Benito Romano también el Consejo Directivo Nacional de la CGTA. Desde algunos años antes (siendo Atilio Santillán el máximo dirigente nacional de la Fotia), Romano junto a Leandro Fote constituían el ala combativa de la organización.

14. Al introducirlo, la voz over afirma que si bien la primera gran huelga de los trabajadores del azúcar fue en 1949, durante el propio gobierno de Perón, es a partir de 1955 cuando las luchas profundizan sus objetivos: las huelgas de 1959, la Marcha del Hambre de 1961, la ocupación del ingenio Santa Lucía. Sobre la gravitación de Zelarrayán como dirigente sindical en el ingenio y el pueblo de Santa Lucía, véase Mercado, 1997. 
nes a pie, en carros, a caballo o tractores, algunos ataques con piedras y gomeras. Pero, salvo una referencia visual menor, ${ }^{15}$ no se incluyen imágenes de ocupaciones (ni documentales, ni reconstruidas ad hoc) como sí ocurre en cambio en La hora de los hornos o luego en Los hijos de Fierro (Solanas, 1972-1975).

En este último film "de ficción" (o "poema-épico", como lo definió Solanas), el capítulo dedicado al Cordobazo cobra relevancia porque se lo asume como punto de inflexión y por lo ingenioso de una puesta en escena que mezcla imágenes de archivo con reconstrucciones ad hoc (actuaciones) hasta casi confundirlas, y enfatiza lo vertiginoso de los hechos, con un registro al modo de un directo casi fowardeado/acelerado, para finalmente recuperar la dimensión dramática de las muertes. Pero también en este film las ocupaciones de fábrica ocupan un lugar relevante. Ubicadas en el inicio, son parte de las formas de lucha que se despliegan ambientadas en una geografia fabril suburbana en torno a la familia proletaria y la cultura barrial-popular. ${ }^{16}$

El segundo capítulo, titulado "El primer combate o la resistencia fabril", se inicia con escenas actuadas de obreros (metalúrgicos o mecánicos) y obreras (textiles) saliendo en agitación de las fábricas. Allí mismo se presenta a cada uno de los tres hijos de Fierro, que en off contarán su historia en la Resistencia ilustrada con otras secuencias construidas ad hoc que funcionan como flashbacks, mientras el presente de la narración los muestra actuando como activistas sindicales, dirigiendo una asamblea por despidos ocurridos al poco tiempo de la caída de Perón. Del mismo modo que en Los traidores (Raymundo Gleyzer, 1973) -aunque con estilos muy distintos- el film de Solanas destaca el control que el capataz o el calculista realizan sobre el proceso de trabajo: en imagen dentro del taller y aquí explicitado como relato en off del hijo menor. Episodio este último que al igual que en el film de Gleyzer deriva en la acción gremial reivindicativa (agitativa-organizativa) de los respectivos protagonistas. En Los hijos de Fierro, a diferencia de otros films, la escena de la ocupación tiene lugar dentro de la fábrica (en las oficinas) e incluye la toma de los directivos como rehenes, un tipo de acción que introduce desde ese inicio una tensión que se relaja

15. Muy breves imágenes documentales de un cartel sobre un alambrado perimetral (“Estamos aquí por defender lo nuestro. ¡Nadie nos sacará!!”) o luego una pintada con reclamos en el Ingenio Los Ralos (pero fechada 14 de enero de 1970) junto a dos jóvenes que con palos parecen custodiar instalaciones tomadas.

16. En su detallado estudio del film (comparado con el Martín Fierro de Torre Nilsson, de 1968), Eduardo Romano (1991: 150-151) consideró como "uno de sus mayores aportes cognitivos [...] la indagación de hasta dónde la familia proletaria fue el más sólido respaldo de toda la Resistencia y cómo una arraigada cultura popular pudo enfrentar incluso los intentos manipuladores de los medios". 
momentáneamente con los festejos y el asado en el patio para culminar con el violento desalojo por parte de la infantería y las consecuentes detenciones (todas escenas reconstruidas ad hoc).

\section{Opciones politicas / opciones visuales}

Aunque la radicalidad que por momentos asumió el proceso de ocupaciones fabriles es indudable,${ }^{17} \mathrm{el} \mathrm{mismo} \mathrm{fue} \mathrm{de} \mathrm{algún} \mathrm{modo} \mathrm{observado}$ en sus límites o incluso cuestionado por el cine militante por lo menos en dos aspectos (por cierto diferentes).

Por un lado, el propio grupo Cine Liberación, que como vimos le otorgó un lugar destacado, también observó la necesidad de su "superación" en su opera prima de 1968. En el capítulo "Los límites del espontaneísmo", las frases ya citadas sobre las limitaciones de los sindicatos se ilustran justamente con material de archivo de fuerzas policiales ingresando a un establecimiento ocupado y desalojándolo. De ahí, la necesidad de canalizar revolucionariamente la iniciativa de las masas, como propone la voz over e interpela un sonido ensordecedor sobreimpreso a las imágenes de represión en las calles. En esa línea, el capítulo final, "La guerra hoy", vuelve sobre la tesis de que ante los ejércitos nacionales ("verdaderas fuerzas de ocupación", "neocoloniales") las organizaciones político-sindicales resultan insuficientes, con una argumentación que deriva en la necesidad de asumir el "lenguaje de las armas", de construir el "ejército popular" para una "larga y dolorosa guerra de liberación".

Más arriba nos detuvimos en la construcción de ese vínculo "casi natural" entre luchas sindicales, politicas y acciones armadas, en los testimonios obreros sobre el Cordobazo en los films de Pablo Szir o Enrique Juárez. También el protagonista obrero (otro joven actor) de La memoria de nuestro pueblo (1972) -mediometraje ficcionalizado de Rolando López, del Grupo de Cine 17 de Octubre de Santa Fe- relata una historia (en este caso no la del Cordobazo, sino la de la Resistencia en Santa $\mathrm{Fe}$ ) que concluye con la convocatoria a la violencia popular.

Se trata, como se sabe, de un discurso epocal muy generalizado, que aparece también en El camino hacia la muerte del viejo Reales y Los hijos de Fierro (aunque en estos casos planteado como una opción entre otras válidas), y claramente en Los traidores, donde la agrupación de

17. La toma de rehenes, por ejemplo, preocupó a dirigentes del gobierno o empresarios, que percibieron en este método (también en la ocupación misma) un desafio violento a la propiedad o la organización capitalista de la producción. Por otro lado, piénsese que por supuesto también para la cúpula sindical de las 62 organizaciones esas acciones podian generar incertidumbre: planificadas y controladas por ella, en sí misma tenían un efecto politizador de las bases, que a veces, junto a activistas de izquierda (en sus variantes) podían desbordarlas (Schneider, 2005: 110-111). 
base opositora (luego de la toma de fábrica en parte desactivada por la maniobra del burócrata sindical llamado Barrera) llega a la conclusión de la necesidad de la lucha armada y realiza una acción al respecto: la ejecución del burócrata Barrera por un comando; un final por cierto muy debatido en torno de hacia dónde debía orientarse la violencia revolucionaria.

Por su parte, cuando el libro Operación Masacre de Rodolfo Walsh (1957) fue llevado a la pantalla (entre 1970 y 1972, en el film homónimo, con guión suyo y de Jorge Cedrón), se introdujo luego de la ficcionalización de los hechos un segmento final documental con el testimonio de Julio Troxler. Allí, ilustrada con archivos visuales de ocupaciones fabriles y del Cordobazo (entre otros hechos), se fundamentaba la tesis de la identidad peronismo-clase obrera. Y al mismo tiempo se postulaba su radicalización en la citada línea acción sindical-lucha armada, de algún modo en sintonía con las modificaciones de los respectivos prólogos o epílogos del libro de Walsh (entre su edición original y el momento del film), que por supuesto no eran ajenas a su investigación periodística antivandorista ¿Quién mató a Rosendo?, publicada en las páginas del Semanario CGT durante 1968 y al año siguiente como libro, en vísperas del Cordobazo.

De este modo, casi todos los films militantes del período postularon que las ocupaciones fabriles (o las huelgas y las movilizaciones) encontraban límites derivados del espontaneísmo, la represión y/o la burocracia sindical, según los casos, y en consecuencia debían de allí en más articularse con (y a veces sustituirse por) acciones armadas.

En segundo lugar, una distancia aún más crítica (diferente) respecto de las ocupaciones se refirió en particular a las desarrolladas en el marco del Plan de Lucha de la CGT de 1963-1965, ya que permitian diferentes lecturas. Si por un lado demostraban el potencial del movimiento obrero argentino, por otro formaban parte de la política de "integración" de la burocracia sindical peronista ("golpear para negociar") que así mostraba su poder frente al débil gobierno del presidente Arturo Illia (UCRP), ante los militares siempre al acecho y también en sus disputas (las de Vandor, en particular) con el propio Perón en el exilio.

Si bien las críticas a esa cúpula sindical no estuvieron ausentes en las películas del grupo Cine Liberación -según ya referimos-, su cuestionamiento principal llegaria hacia 1972-1973 con Los traidores. Allí, la agitación sindical de mediados de la década del 60 queda asociada a un acuerdo de la burocracia sindical con sectores militares para desgastar y desestabilizar al gobierno de Illia y facilitar el golpe militar de Onganía de $1966 .{ }^{18}$ Pero en la medida en que la experiencia de tomas

18. Una escena sobre la inauguración de una nueva sede sindical (en mayo de 1966, 
de fábricas era también importante para este grupo de cine a la hora de narrar las acciones del activismo sindical clasista opuesto a la burocracia sindical peronista, en particular en el proceso abierto entre el Cordobazo y el Viborazo (y de alli en más), su puesta en escena resultaba necesaria. De hecho, desde un punto de vista histórico, la inserción de esa experiencia en el film remite a un momento posterior al regreso del peronismo al gobierno en 1973. Ubicada al inicio de la película, presenta la principal acción de confrontación entre los reclamos de las bases obreras y la burocracia sindical, que funciona como desencadenante de las peripecias del conjunto del film (el autosecuestro de Barrera para no perder las elecciones del gremio) y se mantiene en el presente de la narración mientras transcurren los flashbacks donde se despliega la creciente burocratización y corrupción del dirigente sindical durante los años 60 , en paralelo a la construcción de la alternativa político-sindical opositora en el gremio. Esta tendencia opositora encabeza la ocupación. La escena está rodada en su mayor parte desde el exterior de la fábrica, y destaca la reacción de los militantes subidos al alambrado perimetral en actitud hostil hacia los guardaespaldas del burócrata sindical, quienes les piden que abandonen la toma. Si bien al tratarse de un film de ficción hubiese sido también posible la inclusión de alguna escena de la ocupación desde dentro del establecimiento (como en Los hijos de Fierro), se optó en cambio por presentar las partes en conflicto (basesburocracia) con un significante visual (los obreros sobre el alambrado de la fábrica) muy extendido en los registros documentales y televisivos de esos años, cuando tendencias alternativas ejercían o disputaban el liderazgo de algunos sindicatos peronistas. ${ }^{19}$ En el mismo sentido, no es casual que las escenas emblemáticas del Cordobazo (la de los manifestantes contra la policía montada) ocupen un lugar destacado también en esta película de ficción, aquí entremezcladas con otras imágenes

es decir, un mes antes del golpe), muestra a un coronel interpelando (por separado) a Barrera sobre la posición de la CGT en la coyuntura. Si bien Barrera se compromete con un posible golpe, afirma que Vandor no está decidido (parece jugar con esto a una negociación para obtener mayores beneficios). Ante esto, el militar insiste en que desarrollen un plan de lucha y agitación que debilite al gobierno.

19. Nótese, en este sentido, que entre los materiales audiovisuales atribuidos a Cine de la Base que Álvaro Melián (fundador del grupo y co-guionista de Los traidores) depositó en el Archivo Aamod italiano cuando su exilio en Roma, se encuentran varias horas de registros televisivos de acciones obreras en Córdoba en los primeros 70. En algunos rollos pueden observarse tomas de fábrica donde activistas rodean el alambrado o enrejado perimetral o suben a sus techos, al modo en que se recrea en el film. 
televisivas del Viborazo (1971), con un mayor protagonismo de los gremios clasistas cordobeses. ${ }^{20}$

\section{“Cineastas" y movimiento obrero}

Un elemento común al cine militante argentino de esos años es la cercanía que los realizadores tuvieron con el proceso histórico narrado y en el que intentaban intervenir. La investigación del mundo obrero desplegada por Álvaro Melián y Raymundo Gleyzer en la preparación de Los traidores, se refleja no sólo en las detalladas referencias o puestas en escena de la historia de las luchas sindicales, sino en la conciencia del carácter mayoritariamente peronista de las bases obreras; lo cual los llevó -a pesar de su conocida militancia en el PRT-ERP- a configurar en el film una agrupación opositora que, aún en la línea del clasismo, incluye en un lugar determinante (incluso principal) a activistas de base peronistas, ${ }^{21}$ y donde las principales consignas y dirigentes de esa tendencia alternativa se configuran en el film en torno a la tradición y los postulados del sindicalismo peronista combativo, antiburocrático. (Mestman, 2008).

En el caso del grupo Cine Liberación, del mismo modo que ha sido reconocida la destreza de Solanas como realizador cinematográfico, debería recordarse el aporte de Getino, Vallejo o Nemesio Juárez en el vínculo con el mundo obrero. No sólo por su experiencia gremial, en

20. Es notable, por el contrario, una referencia mencionada al pasar por uno de los protagonistas del film de Vallejo, que da cuenta de una suerte de disputa por establecer como punto de referencia unas luchas obreras en lugar de otras. O por lo menos disputar la hegemonía evidente que hacia 1971 (cuando se termina el film) tenía en ese sentido el Cordobazo. El personaje del Pibe (el hijo más joven del viejo Reales) recuerda sus diálogos con un compañero de trabajo, delegado, e introduce una referencia a "los compañeros de Córdoba". Pero ya no en la línea de epicidad de otros films (un registro que en éste corresponde a las imágenes de las luchas tucumanas), sino en relación con las limitaciones y dificultades de las protestas regionales: "Yo sé que los peronistas en estos años tuvimos muchos errores, pero también hicimos lo que nadie fue capaz de hacer. La gente ahora se dejaba estar no porque no tuviese fuerzas sino porque se sentia sola. Cuando nosotros peleábamos todos los dias, parecía que en el resto del país no pasaba nada. Si no me equivoco nadie hizo ni un paro de un minuto por nosotros. Y es un poco lo que pasa ahora con los compañeros de Córdoba".

21. A diferencia de lo postulado sólo un año antes en el Comunicado del ERP $n^{\circ} 5$ y 7 (sobre el secuestro del cónsul británico y gerente del Swift, Stanley Silvester, y su intercambio por dinero junto a mercaderías o mejoras para los obreros), aquí ya no se explicita la necesidad de una ligazón entre las agrupaciones sindicales y el ERP. 
algún caso, ${ }^{22}$ sino también como realizadores ya no simplemente de películas, sino de noticieros o documentales para las propias organizaciones obreras, algunos con importante repercusión en esos años: desde la participación de los tres en el Cineinforme n. 1 de la CGT de los Argentinos a comienzos de 1969 hasta los Testimonios de Tucumán en 1972 y los Testimonios de la Reconstrucción de 1974 que realizó Vallejo para la televisión tucumana en estrecho vínculo con la FOTIA, o los Cinetestimonios de la Autogestión de Nemesio Juárez sobre el proceso Segba bajo la dirección del sindicato de Luz y Fuerza hacia 1973-1974.

En este sentido, pensamos que no habría que subestimar el impacto de escenas como las de las ocupaciones respecto de otras tal vez más difundidas o más llamativas. En 1970, por ejemplo, la Unidad Móvil Rosario del grupo Cine Liberación, con un trabajo sistemático de proyección de la segunda parte del film entre sectores obreros, había elegido el episodio de las ocupaciones fabriles de La hora... (lo habia cortado, extraído del film) para su uso (junto a otros materiales) en proyecciones en el barrio Bajo Saladillo ante un conflicto gremial en la empresa Swift de la zona. ${ }^{23}$ Aunque conocemos menos fuentes que den cuenta de la difusión de los films especialmente dedicados al Cordobazo, podría conjeturarse también un alto impacto de las imágenes del mismo en esos años.

De ningún modo se trata de que entre los grupos del cine militante hubiera opciones políticas $u$ opciones visuales excluyentes respecto de las luchas del periodo. ${ }^{24}$ Pero sí de proponer una observación más detenida del uso de los materiales de archivo en los films.

Estas notas intentaron indagar cómo en los años 60-70 en la Argentina el ímpetu revolucionario podía simbolizarse a través de más de un tipo de imagen de la protesta obrera. Tanto las de ocupaciones fabriles como las del Cordobazo se configuraron sin duda en potentes simbolos

22. Como también vimos en Getino, es el caso de Enrique Juárez como trabajador de Segba y luego fundador y dirigente de la JTP.

23. Junto a Carlos Schork, Jorge Jäger, Noemí Escandell (entre otros), también Humberto Barroso fue un activo miembro del Grupo Pueblo de Rosario-Unidad Móvil de CL. Se había acercado a Cine Liberación para la difusión de La hora de los hornos en torno a los sucesos del Rosariazo, siendo estudiante de artes visuales y convocado desde un grupo de la izquierda trotskista. Luego, en su experiencia, cargando proyector y rollos por los barrios de Rosario y otras ciudades, se vincularía al peronismo.

24. Así como Cine Liberación se interesó desde temprano en el proceso de ocupaciones fabriles, la irrupción obrera en las calles de Córdoba, Rosario (y otros sitios) en 1969 también atrajo al grupo al punto de llevarlo a modificar sus planes inmediatos en torno a un proyecto de film regional-latinoamericano y en cambio convocar a otros cineastas para el film colectivo Los caminos de la liberación. 
de la resistencia u ofensiva popular. Es cierto que no es lo mismo tomar una fábrica que destruir su producción y ocupar una ciudad. Es decir, no son lo mismo las secuencias de archivo o escenas (re)construidas de las fábricas ocupadas por masas trabajadoras durante el Plan de Lucha de la CGT de 1964 (anteriores o posteriores), que aquellas emblemáticas de los manifestantes haciendo retroceder a la policía montada o las de los obreros mecánicos destruyendo locales de concesionarias o incendiando su propia producción (los automóviles) en las barricadas del centro de la ciudad de Córdoba. Pero tampoco es lo mismo destruir la propiedad privada que "expropiarla" (siquiera por unas horas), tomando a los directivos como rehenes y demostrando la capacidad obrera de batir récords de producción. Más allá del alcance limitado de estas últimas acciones, y aunque resultara dificil obtener registros directos de ellas, su alusión o aún su puesta en escena documental o ficcional, según vimos, proveía otros potentes simbolos del poder obrero que -aunque a veces menos recordados- el cine político también desplegó en su afán por intervenir en las luchas de esos años.

\section{Bibliografia}

Bisio, R. y Cordone, H. (1989), "El Plan de Lucha de la CGT en 1964”, Justicia Social, año $5, \mathrm{n}^{\circ} 8$.

Bourdé, Guy (1978), "La CGT argentine et les occupations d'usines de maijuin 1964", Le Mouvement Social, n 103.

Campi, Daniel y María Cecilia Bravo (2010), "Aproximaciones a la historia de Tucumán en el siglo XX. Una propuesta de interpretación”, en Fabiola Orquera, Ese ardiente jardín de la República..., Córdoba: Alción.

Cotarelo, Maria C. y Fabián Fernández (1995), La toma de fábricas. Argentina, 1964, Buenos Aires: PIMSA, no 2.

Ghigliani, Pablo (2009), El Cordobazo, mimeo.

Marrone, Irene y Mercedes Moyano Walker (comps.) (2006), Persiguiendo imágenes. El noticiario argentino, la memoria y la historia 1930-1960, Buenos Aires: Editores del Puerto.

Mestman, Mariano y Fernando Martín Peña (2002), "Una imagen recurrente. La representación del Cordobazo en el cine argentino de intervención politica", Film Historia (on line), vol. XII, no 3 , Barcelona.

Mestman, Mariano (2008), "Mundo del trabajo, representación gremial e identidad obrera en Los traidores (1973)", Nuevo Mundo Mundos Nuevos, París, 2008. URL: http:// nuevomundo.revues.org/index44963.html.

Mercado, Lucía (1997), El Gallo Negro. Vida, pasión y muerte de un ingenio azucarero, Buenos Aires: s/e.

Pozzi, Pablo y Alejandro Schneider (2000), "El Cordobazo y el auge de ma- 
sas", en Juan Carlos Cena (comp.), El Cordobazo, una rebelión popular, Buenos Aires: La Rosa Blindada.

Pucci, Roberto (2007), Historia de la destrucción de una provincia. Tucumán 1966, Tucumán: Ediciones del Pago Chico.

Romano, Eduardo (1991), Cine y literatura, Buenos Aires: Catálogos.

Schneider, Alejandro (2005), Los compañeros. Trabajadores, izquierda y peronismo, 1955-1973, Buenos Aires: Imago Mundi.

Schneider, Alejandro (comp.) (2009), Trabajadores, Buenos Aires: Herramienta.

Varela, Mirta (2005), La televisión criolla, Buenos Aires: Edhasa.

Walsh, Rodolfo (1957), Operación Masacre (1972), Buenos Aires, De la Flor.

$$
* * *
$$

Resumen: Este artículo analiza los modos en que el cine político argentino representó las protestas obreras entre mediados de la década de 1960 y comienzos de la siguiente, con particular atención a las ocupaciones de fábricas y la lucha de calles. El estudio focaliza en la correspondencia de las imágenes utilizadas respecto de acontecimientos precisos del proceso histórico. Y recorre las producciones filmicas realizadas entre dos películas emblemáticas, como La hora de los hornos (1968), del grupo Cine Liberación vinculado al movimiento peronista, y Los traidores (1973), del grupo Cine de la Base vinculado al PRTERP. Asimismo, argumenta sobre una suerte de disputa entre los grupos de cine respecto de las imágenes que consideraban más representativas de las luchas populares del período.

Palabras clave: cine político - protesta obrera - ocupaciones fabriles - Cordobazo

\begin{abstract}
Focusing on the depiction of factory occupations and the workers struggles in the street, this article discusses how political argentine cinema represented working class protests from the mid 1960s to the beginning of the following decade. By exploring the use of footage and its relation to the events depicted in two emblematic films of the period, La hora de los hornos (1968, made by the peronist group Cine Liberación) and Los traidores (1973, produced by Grupo cine de la Base, linked to the PRT-ERP) this paper points out the presence of a sort of political dispute over the most representative images of popular struggles of those years.
\end{abstract}

Keywords: political cinema - labour protest - factory occupations - Cordobazo

Recepción: 10 de noviembre de 2013. Aprobación: 27 de febrero de 2014 . 